\title{
Correction to: The Fubini Product and Its Applications
}

\author{
Otgonbayar Uuye ${ }^{1}$ [D $\cdot$ Joachim Zacharias ${ }^{2}$
}

Published online: 13 March 2020

(c) The Author(s) 2020

\section{Correction to: Bull. Malays. Math. Sci. Soc. https://doi.org/10.1007/s40840-020-00909-8}

The article The Fubini Product and Its Applications, written by Otgonbayar Uuye and Joachim Zacharias, was originally published electronically on the publisher's internet portal on 11 February 2020 without open access. With the author(s)' decision to opt for Open Choice, the copyright of the article changed on 5 March 2020 to (C) The Author(s) 2020 and the article is forthwith distributed under a Creative Commons Attribution 4.0 International License (https://creativecommons.org/licenses/by/4.0/), which permits use, sharing, adaptation, distribution and reproduction in any medium or format, as long as you give appropriate credit to the original author(s) and the source, provide a link to the Creative Commons licence, and indicate if changes were made.

Open Access This article is licensed under a Creative Commons Attribution 4.0 International License, which permits use, sharing, adaptation, distribution and reproduction in any medium or format, as long as you give appropriate credit to the original author(s) and the source, provide a link to the Creative Commons licence, and indicate if changes were made. The images or other third party material in this article are included in the article's Creative Commons licence, unless indicated otherwise in a credit line to the material. If material is not included in the article's Creative Commons licence and your intended use is not permitted by statutory regulation or exceeds the permitted use, you will need to obtain permission directly from the copyright holder. To view a copy of this licence, visit http://creativecommons.org/licenses/by/4.0/.

Publisher's Note Springer Nature remains neutral with regard to jurisdictional claims in published maps and institutional affiliations.

The original article can be found online at https://doi.org/10.1007/s40840-020-00909-8.

Otgonbayar Uuye

otogo@num.edu.mn

Joachim Zacharias

Joachim.Zacharias@glasgow.ac.uk

1 Institute of Mathematics, National University of Mongolia, Ikh Surguuliin Gudamj

1, Ulaanbaatar, Mongolia

2 School of Mathematics and Statistics, University of Glasgow, 15 University Gardens, Glasgow G128QW, Scotland, UK 